\title{
FURTHER STUDIES ON THE EVOLUTION OF MANIOLA JURTINA IN THE ISLES OF SCILLY
}

W. H. DOWDESWELL

Biology Department, Winchester College

E. B. FORD

Genetics Laboratory, Zoology Department, Oxford

K. G. McWHIRTER

Genetics Laboratory, Zoology Department, Oxford

Received I.ix.59

WE have studied evolution in the butterfly Maniola jurtina (Satyridæ) since 1946. Part of the work has been conducted in the Isles of Scilly, and this aspect of it was last reviewed by Dowdeswell, Ford and McWhirter (1957) and by McWhirter (1957) in articles which carried it up to 1955 . We are now describing it in the succeeding two years, a period during which new and decisive results have been obtained. These arise partly from the response of the jurtina colonies to the weather conditions of 1957 , unprecedented in the Isles during our experience of them and no doubt long before, and partly from the more intense analysis of the insect upon the larger islands which it has now been possible to conduct.

As in the past, we make use of a quantitative character, the number of spots on the underside of the hind wings, for analysing the variability of this species and its response to differing conditions. The extreme stability of their frequency-distributions year by year in certain populations, and their power of rapid adjustment to ecological change in others, indicate that the genes which control spotting are of great selective importance. One of us (W. H. D.) has, moreover, already obtained experimental proof for this conclusion, the details of which will be published in the near future.

\section{THE LARGE ISLANDS}

Between 1950 and 1955 twelve large samples of female $M$. jurtina were taken on St Mary's, St Martin's and Tresco. We have tabulated the spot-distributions (Dowdeswell, Ford and McWhirter, 1957) and shown that they are homogeneous both from year to year and from island to island. This "large island" stabilisation was clearly as firm and as well-established as that of Southern England between the years I $95^{\circ}$ and $195^{2}$, despite the fact that the three populations were isolated from one another by at least a mile of sea. All samples regularly showed the "flat-topped" distribution in which the proportions of females at o spot, at I spot and at 2 spots were approximately equal.

Even by 1954, however, a " second-order" distinction had begun 
to appear between St Mary's on the one hand and St Martin's and Tresco on the other. The proportion of females at three or more spots has, from 1954 onwards, been regularly greater on St Mary's than on the other two islands, and the proportion of females at I spot very slightly less. If a comparison is made as in table $\mathrm{I}$, it will be seen that $\chi_{(4)}^{2}=13.84 ; 0.01>P>0.001$.

Only large-scale and repeated sampling can be expected to bring second-order variations of this kind to light. We have even more intimate knowledge of the "large-island" stabilisation area than of any of the three principle types found on the mainland (that is, the South English, the East Cornish and the West Cornish), and its primary or first-order characteristic (the "flat-topped" distribution) which we have used to define it remains, of course, quite undisturbed.

TABLE I

Comparison of female spotting on St Mary's and on the other two " large" islands, 1950-1955

\begin{tabular}{|c|c|c|c|c|c|c|c|}
\hline Spots & 0 & I & 2 & 3 & 4 & 5 & Total \\
\hline St Mary's 1951-55. & I09 & 90 & 108 & $3^{\circ}$ & $\times 4$ & I & 352 \\
\hline $\begin{array}{l}\text { St Martin's and Tresco, } \\
\text { 1950-55 }\end{array}$ & 412 & $3^{87}$ & 398 & 67 & 23 & I & $\llbracket 288$ \\
\hline
\end{tabular}

In 1956 the first sign of a break-up of this stabilisation could be seen on St Martin's and by 1957 the populations of the Main Areas of both St Martin's and Tresco had moved decisively away from the familiar "flat-topped" distribution, while on St Mary's, the largest island, a much reduced population maintained the same spot-ratios as before. In contrast to the surge of high-spotting which upset the South England stabilisation in 1955-57 (see Creed et al., 1959) and reached its peak in 1956 , the disturbance affecting the "large island" stabilisation produced low-spotting in the females and culminated in 1957. Reference to fig. I, however, shows a general trend towards higher spotting in the males from 1955. Although on the mainland no ecological factor could be picked out as having caused changes in selection-criteria, in Scilly the disturbance of the female spot-distribution was clearly due to a number of factors, chief among them drought, which contributed to an acute shortage of grass.

The changes in the $M$. jurtina populations of the large islands are presented in diagrammatic form in figs. I and 2, and are also summarised in tables 2 and 3 .

It is now necessary to take each island separately and to record seriatim the more intimate details of the ecology and of the estimated population size, before going on to consider the disruption of the stabilisation in general and the light it throws on population dynamics. 


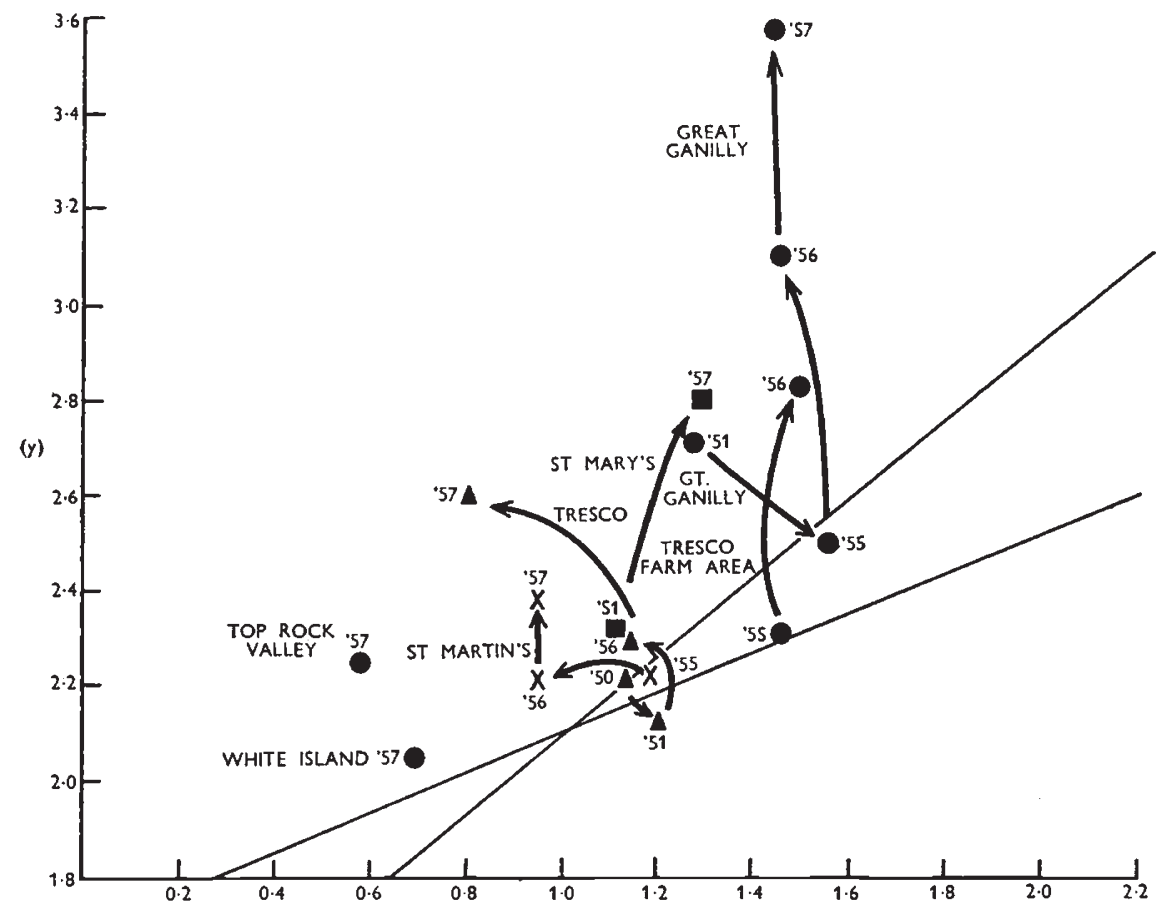

$(x)$

FIG. 1.-The correlation of male ( $y$ axis) with female ( $x$ axis) spot-averages in some Isles of Scilly populations of $M$. jurtina. The regression lines are based on all the data obtained from the Mainland and Scilly between 1946 and 1955 (McWhirter, 1957, fig. I).

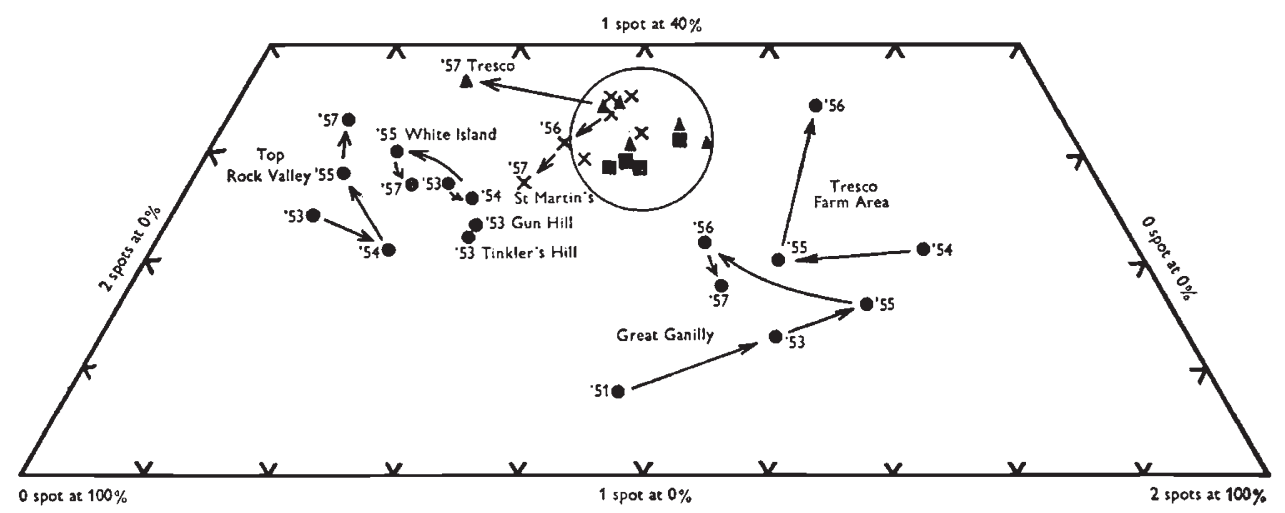

FIG. 2.- Triangular graph showing the frequencies of female $M$. jurtina at o, at $\mathbf{I}$ and at 2 spots expressed as a percentage of the total at o, I and 2 spots (cf. McWhirter, 1957, fig. 2 and Appendix). All large island populations fell within the circle during the period of stabilisation between 1950 and 1955 ( $\boldsymbol{A}$ Tresco ; X St Martin's ; $\square$ St Mary's ; small islands or enclaves of the large islands). 
TABLE 2

Spot-numbers of the large island populations of $\mathrm{M}$. jurtina in 1956 and 1957

\begin{tabular}{|c|c|c|c|c|c|}
\hline $\begin{array}{l}\text { Island and } \\
\text { year }\end{array}$ & $\begin{array}{l}\text { St Martin's } \\
\text { 1956 }\end{array}$ & $\begin{array}{c}\text { Tresco } \\
\text { I } 956\end{array}$ & $\begin{array}{l}\text { St Martin's } \\
\text { I957 }\end{array}$ & $\begin{array}{l}\text { St Mary's } \\
1957\end{array}$ & $\begin{array}{c}\text { Tresco } \\
1957\end{array}$ \\
\hline \multicolumn{6}{|c|}{ Males } \\
\hline $\begin{array}{l}0 \\
\text { I } \\
2 \\
3 \\
4 \\
5\end{array}$ & $\begin{array}{r}2 \\
10 \\
71 \\
21 \\
7 \\
1\end{array}$ & $\begin{array}{r}1 \\
5 \\
47 \\
21 \\
1 \\
2\end{array}$ & $\begin{array}{r}1 \\
6 \\
29 \\
19 \\
3 \\
2\end{array}$ & $\begin{array}{r}\ldots \\
\cdots \\
4 \\
4 \\
2 \\
\cdots\end{array}$ & $\begin{array}{r}1 \\
\cdots \\
6 \\
5 \\
3 \\
\cdots\end{array}$ \\
\hline $\begin{array}{l}\text { Total . } \\
\text { Spot-averages }\end{array}$ & $\begin{array}{l}\text { I I I } \\
2.23\end{array}$ & $\begin{array}{r}77 \\
2 \cdot 29\end{array}$ & $\begin{array}{r}60 \\
2 \cdot 38\end{array}$ & $\begin{array}{l}\text { 10 } \\
2 \cdot 80\end{array}$ & $\begin{array}{c}15 \\
2 \cdot 60\end{array}$ \\
\hline \multicolumn{6}{|c|}{ Females } \\
\hline $\begin{array}{l}0 \\
\text { I } \\
2 \\
3 \\
4\end{array}$ & $\begin{array}{r}63 \\
49 \\
43 \\
6 \\
\ldots \\
\end{array}$ & $\begin{array}{r}34 \\
30 \\
34 \\
5 \\
2\end{array}$ & $\begin{array}{c}73 \\
42 \\
42 \\
\text { 10 } \\
\cdots \\
\end{array}$ & $\begin{array}{r}15 \\
12 \\
14 \\
6 \\
\text { I }\end{array}$ & $\begin{array}{r}21 \\
17 \\
8 \\
2 \\
\cdots \\
\end{array}$ \\
\hline $\begin{array}{l}\text { Total . } \\
\text { Spot-averages }\end{array}$ & $\begin{array}{l}16 \mathrm{I} \\
0.95\end{array}$ & $\begin{array}{l}105 \\
I \cdot I 5\end{array}$ & $\begin{array}{l}167 \\
0 \cdot 93\end{array}$ & $\begin{array}{c}4^{8} \\
I \cdot 29\end{array}$ & $\begin{array}{c}4^{8} \\
0 \cdot 8 \mathrm{I}\end{array}$ \\
\hline
\end{tabular}

TABLE 3

Summary of changes in large island populations, 1956-57

\begin{tabular}{|c|c|c|}
\hline $\begin{array}{l}\text { Frequency of } \\
\text { M. juttina }\end{array}$ & $\begin{array}{l}\text { Ecological } \\
\text { changes }\end{array}$ & $\begin{array}{l}\text { Changes in female } \\
\text { spot-distribution }\end{array}$ \\
\hline $\begin{array}{l}\text { St Mary's } \\
\text { Area tenanted was reduced; } \\
\text { numbers much lower. }\end{array}$ & Nothing obvious. & $\begin{array}{l}\text { Nil ; the } 1957 \text { sample con- } \\
\text { forms precisely with those } \\
\text { of } 1951-55 \text {. }\end{array}$ \\
\hline $\begin{array}{l}\text { St Martin's } \\
\text { Area tenanted was reduced; } \\
\text { numbers still high in some } \\
\text { parts of the main area, but } \\
\text { clear overall reduction } \\
\text { occurred in } 1957 \text {. }\end{array}$ & $\begin{array}{l}\text { Trend towards reduction } \\
\text { of grass first obvious in } \\
\text { I } 957 \text {. }\end{array}$ & $\begin{array}{l}\text { Progressive shift to lower } \\
\text { spot-average and to mode } \\
\text { at o spot, during 1 } 956 \text { and } \\
\text { I957. By I } 957 \text { reversion } \\
\text { to the alternative low-spot } \\
\text { stabilisation, peculiar to } \\
\text { this island, had occurred. }\end{array}$ \\
\hline $\begin{array}{l}\text { Tresco } \\
\text { Area tenanted and numbers } \\
\text { were drastically reduced in } \\
\text { 1957. }\end{array}$ & $\begin{array}{l}\text { Many remarkable changes } \\
\text { involving catastrophic } \\
\text { reduction in grass occur- } \\
\text { red in } 1957 .\end{array}$ & $\begin{array}{l}\text { The "flat-topped" stabilis- } \\
\text { ation persisted in } 1956 \text {, but } \\
\text { there was a sudden and } \\
\text { unparalleled reduction in } \\
\text { high spot specimens in } \\
\text { 1957. }\end{array}$ \\
\hline
\end{tabular}


(i) St Mary's

This island was not sampled in 1956 owing to commitments elsewhere, but, as table 2 shows, the "flat-topped" female stabilisation had been maintained into I957. If the I957 females are compared with the three samples obtained in I95I, I954 and I955 (table 4) and the expectations for the categories o spot, I spot, 2 spots, 3 and more than 3 spots, calculated, we obtain $\chi_{(3)}^{2}=0.14 ; 0.99>\mathrm{P}>0.98$. In fact, our sample of 48 females in 1957 could hardly have fitted the previous St Mary's distribution more exactly. So far as could be seen from the very small sample of males (table 2) which it was possible to collect, some increase in male spotting seemed to have taken place in I 957 .

No obvious changes in the ecology of our collecting area were found but the general tendency throughout the southern half of Britain for the 1957 flying populations to be small was much in evidence.

TABLE 4

Comparison of the spot-distributions of female $\mathrm{M}$. jurtina on St Mary's 1951-1957

\begin{tabular}{|c|c|c|c|c|c|c|c|}
\hline Spots & o & I & 2 & 3 & 4 & 5 & Total \\
\hline I95 I-55 & I09 & 90 & I08 & 30 & I4 & I & 352 \\
I957 & I5 & I2 & I4 & 6 & I & 0 & 48 \\
\hline
\end{tabular}

Shortage of time precluded any attempt to make an accurate estimate of the size of the population by the method of mark-release-recapture. We can only say that we devoted some ten net-hours on two days in excellent collecting weather and took no more than 48 females and io males. Such specimens as we found were mainly in good condition; there was no question but that emergence was continuing at least up to the end of August. Grassy areas which had swarmed with $M$. jurtina in I 955 were virtually untenanted. Although our estimate must be subjective, we had no doubt that a considerable reduction in numbers had occurred.

\section{(ii) St Martin's}

In 1956 an increase in the number of o spot phenotypes was observed in the females; this was not, when compared with the five samples of females taken in 1950-5I and r953-55, a significant difference. Tables 2 and 6 give the relevant figures and $\chi_{(3)}^{2}=3.99 ; 0.3>\mathrm{P}>0.2$. However, we found that if the percentage of specimens at o spots, I spot and 2 spots were plotted on a triangular graph, then the datum (40.6 per cent.; $3{ }^{I} \cdot 6$ per cent.; $27 \cdot 7$ per cent.) fell for the first time just outside the small circle into which all previous "large" island data had fitted. Fig. 2, which is based on the percentage system described by McWhirter (1957), illustrates this. No obvious ecological 
change had occurred on the island; it seemed that the alteration in spot-distribution might be a slightly exaggerated example of a tendency of the St Martin's population to develop a small and temporary increase in the o spot phenotypes, as had occurred in I953 and I955 (see also table 5). That this turned out not to be so will be seen from our analysis of the totals of St Martin's Main Area in I 957 on pp. 344-346.

Returning to the Isles of Scilly in 1957 we camped at the southwest corner of St Martin's and used this opportunity to explore the island more minutely than before. By dividing it into small sub-areas we were able to show that these stabilised populations are not mixtures of smaller, differentially adjusted sub-populations but are homogeneous between localities. These more intimate data are discussed and listed below at pp. 344-346 (table Io). Here it is only necessary to note the totals for the whole of the St Martin's stabilisation area (table 2) and to remark that, compared with $195^{6}$, the spot-averages had further declined and the mode at o spots in the females had markedly increased. The spot-averages are listed in table 5, and the datum for the main St Martin's stabilisation in 1957 is also entered in fig. 2. From this it will be seen that the shift in I 957 was a further departure from the normal "large island" stabilisation and continued the smaller movement recorded in 1956 .

It may also be noted from table 2 and fig. 2 that the number of female specimens at I spot and at 2 spots was equal and that the main St Martin's datum for I 957 is not far from the two data for St Martin's "South-East" (the Gun Hill area) and St Martin's "North-West" (the Tinkler's Hill area) which were obtained in I953. If the two female samples obtained in I 953 from these isolated enclaves and that taken from the main stabilised area of St Martin's in 1957 are compared, as in table 7 , we find that they closely approximate, with $\chi_{(6)}^{2}=2.62 ; 0.9>\mathrm{P}>0.8$. Thus there is evidence that the genetic structure of the St Martin's population is such that in response to certain changes in selection-pressures it is able to develop an alternative stabilisation. This is of interest when it is recalled how the populations of the great South English stabilisation moved to two alternative spot-patterns, which in that case involved reduced modes of o spots, around the year I955 (Creed et al., I 959). We may characterise this "St Martin's alternative stabilisation" as one which produces a female spot-pattern with a mode of somewhat less than $5^{0}$ per cent. at o spots, and with the I spot and 2 spot levels equal at somewhat less than 25 per cent.

It was an obvious task to try to collect samples from the two enclaves, Gun Hill and Tinkler's Hill (marked on fig. 3 as sub-areas " $G$ " and " $H$ " respectively), again. Unfortunately we encountered cold weather with high winds, which heavily reduced the flying population in the Main Area of St Martin's and prevented us catching a single specimen in the enclaves. If these were tenanted, however, it is probable that their populations were small. 
Although we could detect no obvious ecological changes in the main area of St Martin's in 1956, the effects of the spring drought were apparent in 1957 . They were not so drastic as those in the isolated Top Rock Valley area, described on pp. 348-35o, but reduction, as opposed to destruction, of bramble was marked and rabbits appeared to be unusually common. Shelter from long grass and herbs was generally much diminished. Accordingly we supposed that the stabilised population on St Martin's, which had resisted all the climatic vagaries of the years $1950-55$, had responded to the exceptional drought

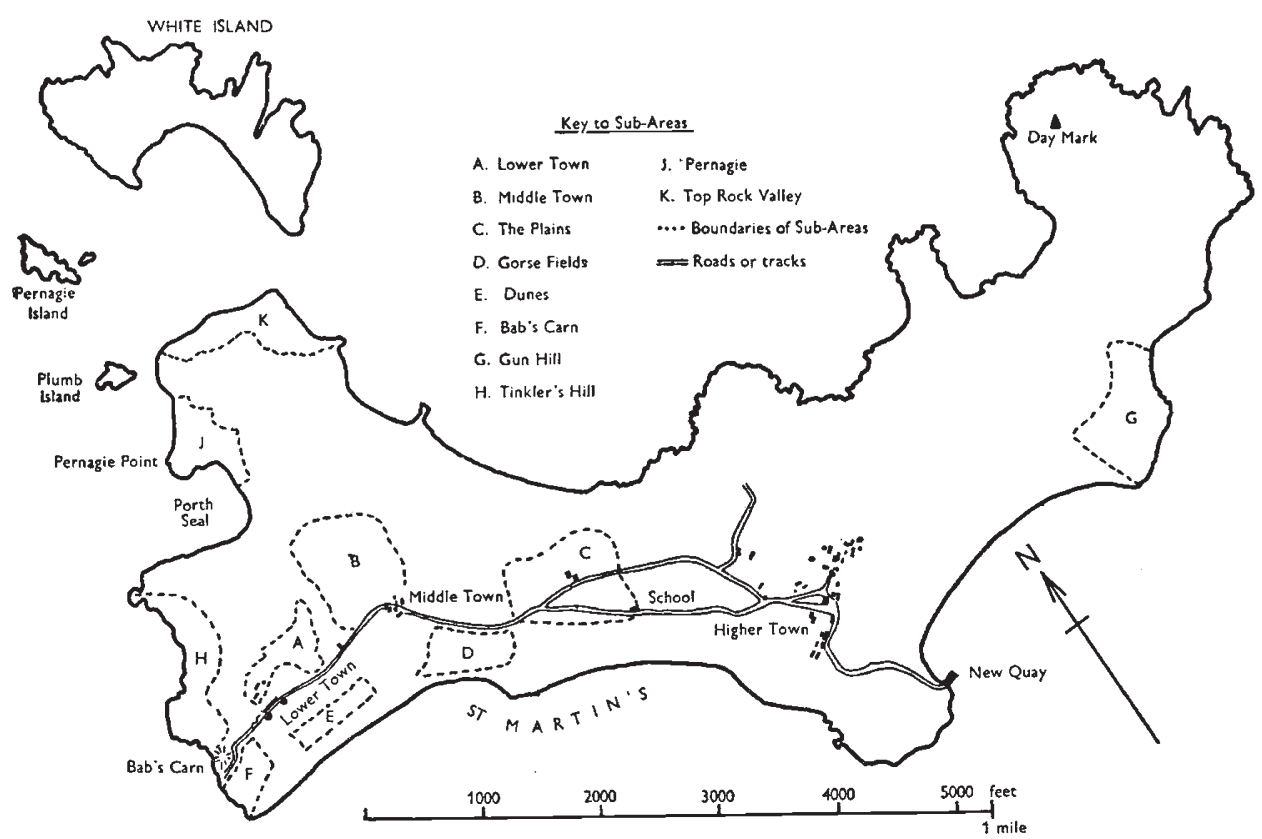

FIG. 3.-St Martin's and White Island, showing the boundaries of the collecting areas from which samples of M. jurtina have been taken. The samples recorded as St Martin's Main Area between $195^{\circ}$ and $195^{6}$ were collected in sub-areas B, C and D.

of $1956-57$ by moving over to its alternative and lower-spotted stabilisation, so that if the 1956 and 1957 female samples are compared with those of $1950-55, \chi_{(3)}^{2}=8.04 ; \mathrm{P}<0.05$. (This and other comparisons are recorded in table 6.) As will be seen from pp. 344-346, all sub-populations of the Main Area performed this movement simultaneously.

A further interesting feature of the situation in St Martin's is that the male spot-average after remaining constant from $195^{\circ}$ to $195^{6}$ increased in 1957 when the female spot-average reached its lowest point. Such disturbances in the male-female correlation, which is normally a strong one (McWhirter, I957), are often noted when a stable condition is upset and are of some theoretical importance (see p. 359). 


\section{(iii) Tresco}

As reference to table 2 and figs. I and 2 will show, on Tresco, the third of the "large islands" which we have studied, no shift from the "flat-topped" female distribution was detectable until I957. In ${ }^{9} 95^{6}$ the appearance of our main collecting area was quite normal. Yet the

TABLE 5

Changes in spot-averages of male and female $\mathbf{M}$. jurtina on St Martin's, Main Area, 1950-1957

\begin{tabular}{|c|c|c|c|c|c|c|}
\hline Year & $\begin{array}{l}\text { Total } \\
\text { male } \\
\text { insects }\end{array}$ & Total spots & $\begin{array}{c}\text { Male } \\
\text { spot- } \\
\text { average }\end{array}$ & $\begin{array}{l}\text { Total } \\
\text { female } \\
\text { insects }\end{array}$ & Total spots & $\begin{array}{c}\text { Female } \\
\text { spot- } \\
\text { average }\end{array}$ \\
\hline $195^{\circ}$ & I I 7 & $25 \mathrm{I}$ & $2 \cdot I 5$ & I09 & I 28 & $\mathrm{I} \cdot \mathrm{I} 7$ \\
\hline $195 \mathrm{I}$ & 293 & 652 & $2 \cdot 23$ & I 16 & 127 & I 09 \\
\hline I953 & $5^{6}$ & I 20 & $2 \cdot 14$ & I I 9 & 120 & $\mathrm{I} \cdot \mathrm{OI}$ \\
\hline I 954 & $\ldots$ & $\dddot{P}$ & $\ldots$ & 237 & 264 & I I I I \\
\hline I 955 & $8 \mathrm{I}$ & I8o & $2 \cdot 22$ & 244 & $290^{\circ}$ & $I \cdot I 9$ \\
\hline 1956 & I I I & 248 & $2 \cdot 23$ & I $6 \mathrm{I}$ & I 53 & 0.95 \\
\hline I 957 & 60 & 143 & $2 \cdot 38$ & I 67 & 156 & 0.93 \\
\hline
\end{tabular}

TABLE 6

Comparison of female M. jurtina in St Martin's Main Area, 1950-5.5 with the 1956, 1957 and combined 1956-57 populations

\begin{tabular}{|c|c|c|c|c|c|c|c|}
\hline Spots & o & I & 2 & 3 & 4 & Total & \\
\hline St Martin's Main Area & 272 & $25 I$ & 247 & $4^{I}$ & 15 & 826 & \\
\hline $\begin{array}{l}\text { I950-55, } \\
\text { St Martin's Main Area } \\
\text { I956 }\end{array}$ & 63 & 49 & 43 & 6 & ... & ${ }_{I} \sigma_{I}$ & $\chi_{(3)}^{2}=3.99 ; 0.3>P>0.2$ \\
\hline $\begin{array}{l}\text { St Martin's Main Area } \\
\text { I } 957\end{array}$ & 73 & 42 & $4^{2}$ & 7 & 3 & 167 & $\begin{array}{l}\text { Compared with I950-55 } \\
x_{(3)}^{2}=7 \cdot \text { I } 5 ; 0 \cdot 10>\mathrm{P}\end{array}$ \\
\hline $\begin{array}{l}\text { St Martin's Main Area } \\
\text { I } 95^{6-57}\end{array}$ & 136 & $9 I$ & 85 & 13 & 3 & $3^{28}$ & $\begin{array}{c}>0.05 \\
\text { Compared with } 1950-55 \\
\chi_{(3)}^{2}==8 \cdot 04 ; \mathrm{P}<0.05\end{array}$ \\
\hline
\end{tabular}

TABLE 7

The alternative lower-spotted stabilisation on St Martin's

( female M. jurtina, 1953 and 1957)

\begin{tabular}{|c|c|c|c|c|}
\hline Spots & $\begin{array}{c}\text { I957 } \\
\text { Main Área }\end{array}$ & $\begin{array}{c}\text { I953 } \\
\text { N.W. Enclave } \\
\text { Tinkler's Hill }(\mathrm{H})\end{array}$ & $\begin{array}{c}\text { I953 } \\
\text { S.E. Promontory } \\
\text { Gun Hill (G) }\end{array}$ & Totals \\
\hline $\begin{array}{c}0 \\
1 \\
2 \\
3 \text { and }>3\end{array}$ & $\begin{array}{l}73 \\
42 \\
42 \\
10\end{array}$ & $\begin{array}{r}5 \mathrm{I} \\
2 \mathrm{I} \\
24 \\
7\end{array}$ & $\begin{array}{r}55 \\
24 \\
27 \\
4\end{array}$ & $\begin{array}{r}179 \\
87 \\
93 \\
21\end{array}$ \\
\hline & ${ }^{1} 67$ & 103 & IIO & $3^{80}$ \\
\hline
\end{tabular}

$\chi_{(6)}^{2}=2.62 ; 0.9>\mathrm{P}>0.8$. 
ecological change which had occurred by August 1957 was the most marked and extensive we have ever seen in the Isles of Scilly. We are convinced that it is not coincidental that the shift between the female spot-distribution of 1956 and that of 1957 is also the most remarkable recorded, not only on the large islands of Scilly but in any population of $M$. jurtina so far.

The most outstanding feature of the ecological situation in the Main Area of Tresco in 1957 was the dearth of grass. Very large stretches of former grassland had been swallowed up in an invasion of Carpobrotus edulis. This succulent herb (better known under the names "Mesembryanthemum" or "Hottentot fig") seems to be a garden escape; it originates from South Africa. C. edulis produces a strongly growing tussock of thick, fleshy leaves with occasional yellow flowers. Grasses are smothered by it.

Mr J. E. Lousley (personal communication, I958) kindly informs us that $C$. edulis "can establish itself in the open on the south coast as far east as Seaford and by comparison with this it seems unlikely that any frost Scilly has experienced recently would affect it very seriously. C. edulis has been established in Scilly for nearly 50 years and my own impression over the last 20 years is that it has increased fairly steadily except for more rapid increases of a local nature following fires. . . . droughts favour an increase in Carpobrotus, and there have been several severe droughts in recent years. Conditions in May and June last year, 1957, may well have favoured rapid elongation of the stems while bracken was short and gave little shade. My notes over the last few years repeatedly refer to bracken only a foot in height in places where it was formerly much taller."

Apart from the sudden increase in the rate of spread of Carpobrotus in Tresco, other factors still further reduced the grass crop in 1957. First, the population of rabbits in the collecting area seemed, judged by fæcal traces, to have increased enormously. Secondly, as elsewhere in Scilly, bracken and bramble died back. On one slope facing the western shore, there was, up to 1956 , a flourishing population of $M$. jurtina, which was, however, difficult to catch owing to the tangle of brambles, which allowed many specimens to escape the nets. In I957, it was possible to walk through the much reduced bramble clumps without hindrance, but not one specimen of $M$. jurtina was to be seen there. Poor as the grass was, it is unlikely that starvation reduced the numbers of $M$. jurtina. In a normal year, rabbits do not graze among bramble clumps, and it seems that the relatively lush grass around them affords not only food but perhaps protection from predation to larvæ. In 1957 , however, all the grass was nibbled right up to the centres of the stunted brambles. Increased selection, rather than absolute starvation, seems a more likely reason for the drastic reduction in the flying population of $M$. jurtina.

The result of all these changes was that within a year what had been a reasonable and diverse feeding-ground for $M$. jurtina became a 
restricted semi-desert: only short, poor grass remained. For the insect the habitat was, in 1957, bleaker than any of the windswept areas of White Island or the adjacent part of St Martin's. We have stressed the suddenness of the ecological crisis because it appears to us to explain precisely why selection has operated so strongly against the high-spot specimens (see table 8 ). With great difficulty and the expenditure of twenty net-hours spread over two days of fair to perfect collecting weather we obtained no more than 48 females and i 5 males, the majority of which were perfectly fresh and had obviously only recently emerged. The population in this area has never been dense, but up to 1956 we had generally collected roo females at the expense of ten net-hours and many more specimens were seen but escaped in the more densely vegetated areas. In 1957 nearly every specimen seen was caught.

TABLE 8

Distribution of spot numbers in female Maniola jurtina Tresco, Main Area, 1950-1957

\begin{tabular}{|c|c|c|c|}
\hline & Spots & 1950-56 & 1957 \\
\hline & $\begin{array}{l}0 \\
1 \\
2 \\
3 \\
4 \\
5\end{array}$ & $\begin{array}{r}174 \\
166 \\
185 \\
31 \\
10 \\
1\end{array}$ & $\begin{array}{c}21 \\
17 \\
8 \\
2 \\
\ldots \\
\cdots\end{array}$ \\
\hline Total & . & 567 & 48 \\
\hline
\end{tabular}

The spot-distribution data in $M$. jurtina seem clearly to indicate that the intensity of selection on Tresco has been greater than on St Martin's. On Tresco a catastrophe seems to have overtaken a large and stable population and to have selectively eliminated the highspot specimens at a late stage in their life-cycle (for the drought was most intense during May and June). The percentages of the Tresco females at 0 spots, I spot and 2 spots are now 46 per cent., 37 per cent. and 17 per cent., so that the datum for 1957 has shifted decisively into the low-spot category, as can be seen when it is plotted in fig. 2. The high reading of 37 per cent. for I spot is unprecedented and probably indicative of exceptionally strong disturbance.

It is important to develop a method of estimating the statistical significance of this selective elimination of the more highly spotted female specimens in 1957. From table 8 it can be seen that, if this I957 sample is compared with the homogeneous " flat-topped " samples obtained between I950 and 1956, we obtain $\chi_{(2)}^{2}=7 \cdot \mathrm{I} 9$, with P just exceeding $0 \cdot 02$. (The small size of the 1957 sample makes it necessary to group the data for 2 and more than 2 spots.) It also seems clear that no significant selective elimination took place in 1957 against specimens 
at one spot. If we combine the data for o and I spot we obtain $\chi_{(1)}^{2}=6.10 ; 0.02>\mathrm{P}>0 \cdot 0 \mathrm{I}$, using Yates' correction.

These estimates of heterogeneity, while establishing that a highly significant change took place, are based merely on the abnormal distribution of the 1957 sample. In the biological context, however, we know that a number of high-spotted females which we " expected" to catch in 1957 were not caught (nor even, probably, seen).

Reducing the data to the $2 \times 2$ form, as in table 9 , it appears that the relative frequency of the high-spotted specimens in 1957 was $\frac{a d}{b c}=\frac{10}{227} / \frac{3^{8}}{340}=0.394$. Woolf (1954) has described a convenient method of estimating fiducial limits of the function $\frac{a d}{b c}$, which he terms $x$. Applying this technique to ascertain the 95 per cent. confidence limits we find them to be 0.193 and 0.807 .

TABLE 9

Data of table 8 reduced to a $2 \times 2$ table

\begin{tabular}{|c|c|c|}
\hline Spots & $1950-56$ & 1957 \\
\hline $\begin{array}{c}\text { ond I . } \\
\text { and more than 2 }\end{array}$ & $340(a)$ & $3^{8(c)}$ \\
Total & $227(b)$ & 10 $(d)$ \\
\hline
\end{tabular}

The same result can be reached intuitively after a consideration of the biological situation. On the null hypothesis that no selective elimination of the high-spotted females was taking place, we should have expected to catch $\frac{227}{340} \times 38=25.4$ insects in this category in 1957 . Since in fact ro such specimens were caught the deficiency was $25 \cdot 4-\mathrm{Io}=\mathrm{I} 5 \cdot 4$, and the percentual elimination was $\frac{\mathrm{I} 5 \cdot 4}{25 \cdot 4} \times \mathrm{I}$ oo $=60 \cdot 6$ per cent. Algebraically this estimate is:

$$
\frac{\left(\frac{b}{a} \times c\right)-d}{\left(\begin{array}{l}
b \\
a
\end{array} \times c\right)}=\mathrm{I}-\frac{a d}{b c}=\mathrm{I}-x .
$$

Again applying Woolf's method, the selective elimination of highspotted females in I 957 was $60 \cdot 6$ per cent. with 95 per cent. fiducial limits at 80.7 per cent. and 19.3 per cent. This calculation allows for sampling error in all four cells of the $2 \times 2$ table, but since virtually the whole flying population was netted on two days in 1957, one of the sources of sampling error may have been diminished in that 
year, so that intuitively one may be led to the conclusion that the 95 per cent. fiducial limits are not so wide as those estimated above.

This is the strongest selection pressure against a group of widespread phenotypes in a variable wild population that has ever been recorded. We cannot as yet, owing to the difficulty of pairing $M$. jurtina, offer any precise suggestions as to what such high selective elimination during one generation of the high-spotted female phenotypes may mean in terms of gene-frequencies, but since there is evidence from population data that spot-numbers are closely governed by the genotype, we should expect to see some signs of the I957 crisis in later samples which we hope to obtain from the Main Area of Tresco.

It is also of importance to note that while the females on Tresco suffered a heavy reduction in spot-average in 1957 , the males, on the contrary, so far as we can judge from a rather small sample, became more high-spotted than before (see table 2). The male spot-average in $195^{6}$ was $2 \cdot 33$, which is higher than usual for the large-island populations, while in 1957 it reached $2 \cdot 60$ (see fig. I).

\section{(iv) Local homogeneity of the population in St Martin's}

(Main Area)

In 1957 we attempted for the first time to analyse one of the stabilised large-island populations in detail. We had for long felt that, except in places where isolation was constant and effective, the large islands supported a population which was adapted to the general mixed ecology of the extensive habitat and had developed an appropriate genetic structure (Dowdeswell and Ford, 1953). Nevertheless, we decided that we should test the possibility that our largeisland stabilisation might be composed of a mixture of insects derived from a number of relatively isolated habitats, each of which had developed a specialised population, some with modes at o spots and some with modes at 2 spots.

To obtain further evidence for or against the hypothesis of mixture, we divided the Main Area of St Martin's into six sub-areas, following boundaries which separated regions of different cultivation and of different natural ecology so far as possible. The approximate limits of the six sub-areas are recorded in fig. 3. Our 1957 sample was registered with reference to these sub-areas, except that on one occasion we mixed small samples from Lower Town and from Middle Town after it had become apparent that the two gave homogeneous results. The breakdown of the sample from the Main Area of St Martin's into sub-areas is recorded in table $\mathrm{I}$.

The characteristics of the sub-areas are as follows:

"A" Lower Town. This sub-area stretches from the cluster of houses called Lower Town up to the crown of the west end of the island. The land is mostly devoted to small bulb fields, covered in summer with grass and herbs, and usually surrounded by wind-breaks of Pittosporum and Veronica exceeding ten feet in height. 
M. jurtina was more abundant here than in any other place on the large islands which we visited in 1957 .

"B" Middle Town. This sub-area is more exposed than "A". It forms a horse-shoe round a deep cleft running from Middle Town up to the crown of the west end of the island. The land is less intensively cultivated than that of sub-area "A" ; the higher parts are covered with bracken and bramble.

" C" The Plains. Sub-area " C" occupies the Plains, an exposed plateau above Middle Town. Even here, however, there is some shelter from the wind in lanes and dells covered with bramble and bracken. Half of this sub-area lies on the south side of the road, which forms no barrier to the insect. Parts of " $\mathrm{G}$ " which had swarmed in recent years with $M$. jurtina to such an extent that three or four specimens were often in the net together, carried very small populations in 1957.

TABLE 10

Breakdown of St Martin's Main Area population of M. jurtina into sub-areas, 1957

\begin{tabular}{|c|c|c|c|c|c|c|c|}
\hline \multirow{2}{*}{ Sub-area } & \multicolumn{6}{|c|}{ Spots } & \multirow{2}{*}{ Total } \\
\hline & 0 & I & 2 & 3 & 4 & 5 & \\
\hline \multicolumn{8}{|c|}{ Males } \\
\hline $\begin{array}{l}" \mathrm{~A} " \\
" \mathrm{~B} " \\
" \mathrm{C} " \\
" \mathrm{~A} "+ \\
" \mathrm{~B} "\end{array}$ & $\begin{array}{l}\cdots \\
1 \\
\cdots \\
\cdots\end{array}$ & $\begin{array}{r}2 \\
1 \\
3 \\
\cdots\end{array}$ & $\begin{array}{r}4 \\
8 \\
17 \\
\cdots\end{array}$ & $\begin{array}{l}3 \\
6 \\
8 \\
2\end{array}$ & $\begin{array}{c}I \\
I \\
\cdots \\
I\end{array}$ & $\begin{array}{l}\cdots \\
\text { I } \\
\text { I }\end{array}$ & $\begin{array}{r}10 \\
18 \\
28 \\
4\end{array}$ \\
\hline \multicolumn{8}{|c|}{ Females } \\
\hline $\begin{array}{l}\text { "A" } \\
" \mathrm{~B} " \\
" \mathrm{C} " \\
" \mathrm{~A} " \\
" \mathrm{~A} "+\mathrm{B} "\end{array}$ & $\begin{array}{r}26 \\
27 \\
16 \\
4\end{array}$ & $\begin{array}{r}10 \\
22 \\
8 \\
2\end{array}$ & $\begin{array}{r}12 \\
17 \\
10 \\
3\end{array}$ & $\begin{array}{l}2 \\
2 \\
3 \\
\cdots\end{array}$ & $\begin{array}{c}\cdots \\
2 \\
1 \\
\cdots\end{array}$ & $\begin{array}{l}\ldots \\
\cdots \\
\cdots \\
\cdots\end{array}$ & $\begin{array}{r}50 \\
70 \\
38 \\
9\end{array}$ \\
\hline
\end{tabular}

"D" Gorse Fields. This sub-area lies south and west of " $\mathrm{C}$ " and wholly on the south side of the road. On the east it is composed mainly of fields which have gone out of cultivation and now contain large clumps of gorse. Towards the west it fades into the sand-dunes which line the south coast. " $\mathrm{D}$ " has been very well populated with $M$. jurtina, but not one specimen was caught there in 1957 .

" $\mathrm{E}$ " The Dunes. This sub-area lies along the south coast to the west of " $\mathrm{D}$ ". No insects were caught here in 1957.

"F" Bab's Carn. This sub-area occupies the south-western corner of the island and is dominated by Bab's Carn, a prominent rock which forms the north-western boundary. It seems to be isolated from the rest of the island by the buildings of Lower Town to the north, by the sea to the south and west, and by highly cultivated fields and unoccupied sand-dunes to the east.

We calculate that the female populations of sub-areas "A ", " B " and " $\mathrm{C}$ " are substantially homogeneous $\left(\chi_{(4)}^{2}=3 \cdot 68 ; 0.5>\mathrm{P}>0 \cdot 3\right)$. Sub-area "F" (see table II), when compared with sub-areas "A ", " $\mathrm{B}$ " and " $\mathrm{G}$ " grouped together gives $\chi_{(2)}^{2}=3.49 ; 0.2>\mathrm{P}>0 \cdot \mathrm{r}$. Thus it does not differ significantly from the rest. However, in view of the apparent deficiency of female specimens at i spot and of the fact 
that this sub-area may be isolated and has not been previously sampled, we have excluded it for the time being from the Main Area of St Martin's (see table I I).

From the results of the sampling of sub-areas "A ", " $B$ " and " $\mathrm{C}$ ", we are satisfied that the large island stabilisation does in fact represent a genetic condition evolved as a response to mixed ecology. Thus it appears that all parts of the Main Area of St Martin's, now defined as being composed of at least sub-areas "A ", "B " and " $\mathrm{C}$ ", have taken part simultaneously in the shift to the alternative, lower-spotted stabilisation.

TABLE II

Spot-frequencies of M. jurtina in St Martin's Area "F" (see p. 345)

\begin{tabular}{|l|c|c|c|c|c|c|c|}
\hline \multicolumn{1}{|c|}{ Spots } & 0 & $\mathrm{I}$ & 2 & 3 & 4 & 5 & Total \\
\hline Males & $\ldots$ & $\ldots$ & 3 & $\mathrm{I}$ & 2 & $\mathrm{I}$ & 7 \\
Females & 9 & 2 & 9 & $\mathrm{I}$ & $\ldots$ & $\ldots$ & $2 \mathrm{I}$ \\
\hline
\end{tabular}

\section{ISOLATED AREAS ON LARGE ISLANDS}

\section{(i) The "Farm Area"}

If, as we believe, the uniformity of female spotting on the large islands in Scilly has developed in response to the average of the diverse conditions existing on them, we might expect any small isolated population to achieve a local adjustment differing from that of the island as a whole. One such colony was found on Tresco in I954, occupying $200 \times 70$ yards of rough ground (the "Farm Area"). This was used by the Royal Navy during the I9I4-I 8 war and huts were built upon it. Their concrete foundations remain and around them has grown up rank vegetation of a highly exceptional kind, mostly garden escapes unsuitable as food for jurtina. The site, which included pigsties in 1955 and $195^{6}$, is bounded to the north by estate workshops and a village, to the west by the shore and to the east by a road and hedge bordering a narrow strip of grass beyond which is a lake. Southwards, between the sea and extensive pine woods, is a tract of bracken, bramble and very short turf; $M$. jurtina cannot colonise this type of habitat, but a path leading to the main collecting grounds of the island traverses it. This may provide a passage for the insect, but no appreciable flow of the butterfly has been observed here even when it was quite plentiful.

The colony inhabiting the Farm Area, totalling no more than Ioo to I50 flying insects, was studied in I954 and I955 (Dowdeswell et al., I957). The spotting of the females was similar in the two years 
and differed significantly from that of the colony inhabiting the main part of Tresco, which had itself remained constant not only during that time but since first examined, in I $95^{\circ}$.

On visiting the area in $195^{6}$ we found the ecology somewhat changed. A field bordering the path running south from it, which had previously supported a dense growth of Red Campion (Melandrium dioicum), was now ploughed and sown with grass. Maniola jurtina was flying freely here, suggesting the possibility of a leakage from the Main Area of Tresco. This was tested by marking as many of the "Farm Area" population as could be caught in a single day (35 males; 36 females). A subsequent sample collected six days

TABLE I2

Female spot-distributions of $\mathrm{M}$. jurtina in two areas on Tresco

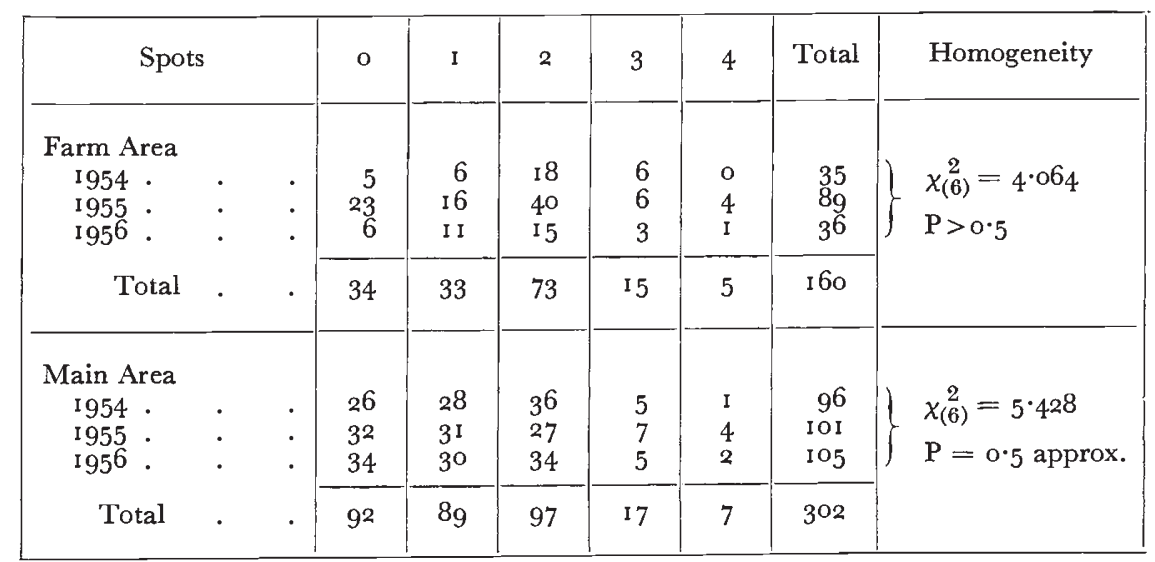

Difference of Farm Area from Main Area $: \chi_{(3)}^{2}=13.816,0.01>P>0.001$.

later included no marked specimens but a high proportion of completely fresh insects of both sexes, which indicated either local immigration or emergence. The fact that spotting in the females proved to be different from that of the only region whence immigrants could have come, demonstrates the latter alternative.

Table I 2 shows that throughout I954-56 female spotting in the Farm Area remained unchanged but differed significantly from that in the Main Area of Tresco, which had also remained constant throughout that period. Thus the spot-frequencies indicate that the insect was responding to exceptional conditions in a restricted and isolated habitat. To this it had become stabilised by selection powerful enough to overwhelm any action of random drift and any influence due to immigration.

On revisiting the area in 1957 , it was at once apparent that great changes had taken place since the preceding year. The pigsties which formerly occupied part of the locality had been removed, leaving a patch of denuded earth. The small amount of grass had been almost 
entirely replaced by a dense mat of Carpobrotus, with the exception of a few square yards in the north-eastern corner where two Maniola jurtina were found. In all, a search of four net-hours revealed only 4 insects (all females), 2 at o spots, I at 2 spots and I unscorable, and it was clear that the population of the Farm Area had been reduced to an extremely low level.

\section{(ii) Top Rock Valley (formerly referred to as the coastal area of St Martin's opposite White Island)}

Reference to fig. 3 shows a strip of the north-west coast of St Martin's about 500 yards long and up to roo yards wide (marked as sub-area " $\mathrm{K}$ "). Here, as already reported (Dowdeswell et al., I957), there is a population of $M$. jurtina whose females are unimodal at 0 spots. Although its habitat is connected at low tide by a rocky bar with White Island, there is no doubt that this population in Top Rock Valley is completely isolated from it. From I953 when it was first sampled, it has maintained a strong heterogeneity against the population of the Main Area of St Martin's, from which it is isolated by a wide band of bare, podsolised soil and by further stretches of poor land covered with bracken. In this region very few specimens of $M$. jurtina have been seen, though it is possible that some slight leakage occurs, as may also be the case in the parallel situation on Tresco (p. 346$)$.

We planned to estimate the size of the population in Top Rock Valley and to plant in it as many females as possible from White Island. It may be assumed that virtually all flying females have already been inseminated. If transferred to another habitat their progeny will therefore carry the genotypes of the original population. After a few generations in which the native population of Top Rock Valley has been flooded with White Island specimens it is hoped to obtain further evidence on the problem posed by the similar adjustments of the two isolated communities. If it is found that the recipient one does not change, then this would suggest either that the White Island genotypes were not mingling with those of the Top Rock Valley population, or that the adjustment to the similar micro-ecological situations in the two habitats has been achieved in substantially similar ways in both. (The second of these alternatives is inherently more probable than the first.) If, on the other hand, we found some disturbance taking place in Top Rock Valley, and if this were not attributable to an alteration in the local micro-ecology, then we would be inclined to think that the similar spot-distributions had arisen by chance from two separate types of genetic adjustment.

This plan has been somewhat disturbed by two adverse events in I957, but we have pursued it so far as possible and intend to continue with it, so long as it is feasible. Firstly, the drought and warmth of the first half of 1957 had a strong influence on the micro-ecology of 
Top Rock Valley. As in so many other habitats in Scilly, the grass became very poor, bracken was sparse and the bramble was strikingly reduced; fæcal traces of rabbits were abundant. Bleached stems over 3 yards long could be seen around some of the bramble clumps indicating the luxuriance of the fruiting growth of 1956 . The 1957 growth was wretchedly poor, sometimes hardly exceeding a foot in length. Very much better growth in 1958 was promised, in that the new shoots were a reasonable length, though they were not so strong as the skeletal remains of 1956 . This cycle of events is important because bramble, especially in exposed places like Top Rock Valley, provides the shelter for what long grass there is. The soil inland from Top Rock Valley and from the coastal area to the west of it, called Pernagie (sub-area " $\mathrm{J}$ " in fig. 3), failed to support the usual luxuriant growth of bracken, which we found to be very short and relatively sparse. This may result in a temporary increase in leakage from the Main Area population on the crown of the island down to the normally isolated northwest coast.

Our second difficulty in carrying out our plan arose from shortterm climatic factors. After estimating the population of Top Rock Valley, we returned to White Island to collect live females, but were confronted with high wind which persisted over three days-an unusual event in August on the Isles of Scilly. From what we knew to be a reasonably abundant population, we were able to catch only I4 females which were liberated in Top Rock Valley.

Our estimate of the population of Top Rock Valley was carried out according to the method of Dowdeswell, Fisher and Ford (1949). A daily survival ratio of 84 per cent. reduced the gap between observed and expected survival to minimal proportions, and the resultant population estimates were 169 on I 9 th August (in perfect collecting weather), $5^{I}$ on 2 Ist August and 90 on 24th August. The two latter days were less favourable. Allowing for sampling errors in an experiment which had to be carried out on rather a small scale, we might suggest a daily flying population of the order of yoo and a total emergence not greatly exceeding I0oo. It is interesting to note that an 84 per cent. daily survival ratio falls between the 89 per cent. calculated by Dowdeswell et al. ( I 949) for the large populations of Tean Areas I and 3 and the 75 per cent. calculated for the small population on the very restricted Tean Area 5. Between I 94I and I945 the calculated daily survival ratio of Panaxia dominula at Cothill was 84 per cent. (Fisher and Ford, 1947).

The female spot-distribution found in Top Rock Valley is recorded in table 13 and conforms fairly closely to the distribution found in the period I953-55. It is, however, becoming apparent that, though the percentages at o spots, I spot and 2 spots remain similar both from year to year and between Top Rock Valley and White Island, there is a marked and significant tendency for the "tail" - that is female specimens at 3,4 and 5 spots-to be well represented in Top Rock 
Valley while it is virtually absent from White Island. Thus a comparison of the summed distributions for Top Rock Valley and for White Island $(1953-57)$ yields $\chi_{(2)}^{2}=2.34 ; 0.5>P>0.3$, when the "tail" is grouped with the 2-spot category, but $\chi_{(3)}^{2}=14.88$; $0 \cdot 0 \mathrm{I}>\mathrm{P}>\mathrm{O} \cdot 00 \mathrm{I}$, when the " tail " is computed separately.

Without the abundant records which we are now accumulating, this difference would be overlooked. It remains firmly established, of course, that the most important adjustments occur in the o spot or 2 spot levels of the females throughout Scilly. The difference in " tail " is an example of a " second-order" variation, and should be compared with the "second-order" distinction between the Main Areas of St Mary's on the one hand and of St Martin's and Tresco on the other (see pp. 333-4), or with the small but significant differences between the males of the eastern and western parts of Southern England (McWhirter, 1957). We are inclined to attribute the high "tail" of the Top Rock Valley population to the influence of leakage from the Main Area of St Martin's where the 3-spot condition is well represented. This view receives a little support from the male distribution recorded for the first time in Top Rock Valley in 1957. Table I3 shows that the spot-average for a small sample of males caught there was $2 \cdot 25$, which is rather high. This small sample may possibly include some Main Area males which have come through the much weakened barrier of bracken. As we have seen in the Farm Area on Tresco, however, the selective forces in peculiar and isolated regions such as Top Rock Valley are quite strong enough to maintain a special genetic structure against pressure from another population.

The phenotypes of the fourteen females released in Top Rock Valley on $24^{\text {th }}$ August were: 7 at o spots, 4 at I spot and 3 at 2 spots.

\section{(iii) Pernagie}

This is a region of large fields of quite a different character from the usual bulb fields on St Martin's. It lies along the north-west coast of the island from Pernagie Point in the south up to the promontory facing Plumb Island 400 yards to the north. It is marked as sub-area " J" in fig. 3. At the present time these large flat fields are not intensively grazed and in the southern portion of the area around Pernagie Point there is much rank grass and undiminished bracken and bramble, somewhat reminiscent of the current condition of Tean Area 3 , and not apparently highly favoured by $M$. jurtina.

We had not until 1957 sampled the Pernagie region, but had collected Top Rock Valley up to the western boundary marked in fig. 3, beyond which the butterfly appeared to be rare. In view of the current plan of assessing the population of Top Rock Valley, however, it seemed to us to be of some importance to explore Pernagie (sub-area "J") more thoroughly. First, there is no real boundary between the two sub-areas. On the other hand, we never found any of the insects 
marked in Top Rock Valley in the Pernagie region. This may simply have been due to the prevailing westerly winds at that time. Secondly, as table 13 indicates, we found that the female population of Pernagie is similar to that of Top Rock Valley in having a marked mode at o spots. The number of specimens at I spot was somewhat lower in Pernagie but these differences are well within the limit of sampling error $\left(\chi_{(1)}^{2}=0.22 ; 0.7>\mathrm{P}>0.5\right)$, and we felt justified in provisionally regarding the Pernagie population as an extension of that of Top Rock Valley and as being isolated in the same way from the populations of the Main Area of St Martin's.

To the south of Pernagie along the coast of Porth Seal, the strip of grazing land narrows until the dense bracken characteristic of the northern slopes of the island comes down to the sea and cuts off the

TABLE 13

Spot-distribution of male and female M. jurtina in two isolated parts of St Martin's

\begin{tabular}{|c|c|c|c|c|c|c|c|c|c|c|c|c|}
\hline & \multicolumn{6}{|c|}{ Male spots } & \multicolumn{6}{|c|}{ Female spots } \\
\hline & o & I & 2 & 3 & 4 & Total & o & I & 2 & 3 & 4 & Total \\
\hline $\begin{array}{l}\text { Top Rock Valley (sub- } \\
\text { area "K") }\end{array}$ & $\cdots$ & I & I4 & 4 & I & 20 & 33 & 19 & 6 & I & $\cdots$ & 59 \\
\hline Pernagie (sub-area "J") & $\cdots$ & $\cdots$ & $\cdots$ & $\cdots$ & I & $\mathbf{I}$ & I3 & 2 & 2 & 3 & I & $2 \mathrm{I}$ \\
\hline Total & $\ldots$ & I & I 4 & 4 & 2 & 21 & 46 & 21 & 8 & 4 & I & 80 \\
\hline
\end{tabular}

Pernagie region from Tinkler's Hill (marked in fig. 3 as sub-area " $\mathrm{H}$ "), and from sub-area " B" which lies a few hundred yards farther to the west. It seems likely that the isolation of the Pernagie popu lation on this flank is virtually complete, though, as in the case of Tof Rock Valley, we suspect there may be some leakage from the Main Area along the footpaths leading into the fields from the east.

\section{SMALL ISLANDS}

\section{(i) Tean}

In a previous paper (Dowdeswell et al., I957), we have summarised the results of our work on Tean during I954 and I955. This revealed certain important changes in the ecology of the island following the removal of a herd of cattle in the late summer of I950. Vegetation which was previously close-cropped had by 1952 grown rank, so that areas which formerly acted as barriers to $M$. jurtina had become colonised by it, and the reverse. The rapid spread of bracken had enabled the population in area I to spread into area 2 (see map, 
Dowdeswell et al., 1957), while retaining the spot-distribution characteristic of area I since 1946. Area 3, where the insect was previously abundant, was now greatly overgrown with bramble and bracken and had become an effective barrier to it. The small colony of jurtina formerly isolated in area 5 had spread into area 4 , which had previously barred its way when the grass had been grazed too closely to provide it with shelter or suitable food. Unlike areas $I$ and 2 which are rather similar, the ecological conditions in areas 4 and 5 are very different from one another. It was not surprising, therefore, to find that the spotting of the butterflies inhabiting them differed both from that in area I (now areas I and 2) and from the type found in area 5 at the time when area 4 was still a barrier.

On visiting Tean in 1956, we found conditions much the same as in the preceding year. The only noticeable difference was a great increase in the rabbit population whose grazing had had the effect of

TABLE I4

Spot-distribution in male M. jurtina on Tean (area I) in I954 and 1956

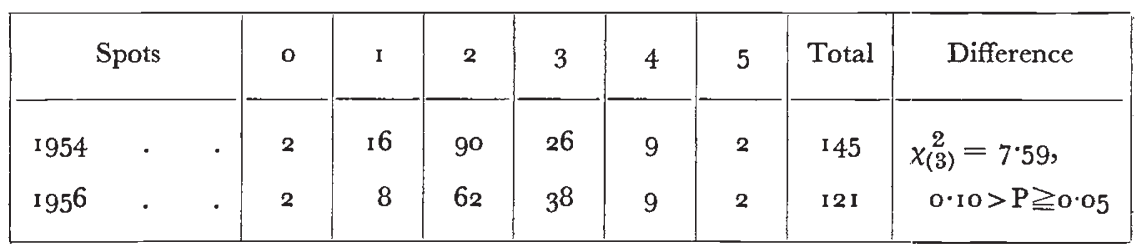

reducing considerably the length of grass in area 4 , and to a lesser extent in area 2. Although not a barrier in 1954, area 4 had become partially so in 1956 . However, observation showed that a small passage of jurtina was still taking place along this western limb of the island.

(a) Males. Previous work on Tean had established that a stable form of spotting (unimodal at 2 spots) had existed throughout the island since our investigations began in 1946 . In I 954 only one male sample was collected (from area I), and this is compared with its ${ }_{195} 6$ counterpart in table I4.

This shows that there had been a tendency towards increased spotting which, however, has not become fully significant during this period: a tendency which appears to have been universal both on the Mainland and in Scilly during these years.

Samples obtained during 1956 in areas I, 2, 4 and 5 are compared in table 15 .

From a $2 \times n$ table it is clear that spotting was homogeneous in all four areas (as far as the small numbers in area 5 permit any opinion to be formed in regard to that habitat), as previous experience would lead us to expect. 
(b) Females. Extensive sampling of the female jurtina population on Tean was last carried out in 1954, and a small collection made from area I in I 955 suggested strongly that no appreciable change had taken place since the previous year. It was therefore of some importance, in view of the rapid alterations in the ecology of the island, to obtain

TABLE I5

Spot-distribution in male M. jurtina on Tean (areas $1,2,4$ and 5) in 1956

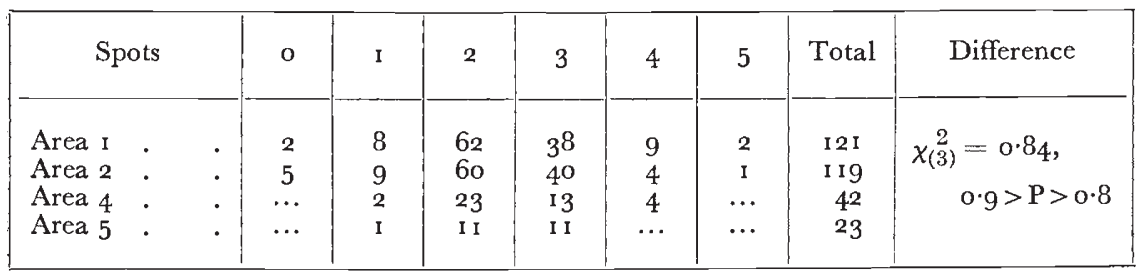

samples in 1956 for comparison with those of two years before. These comparisons are made in table 16.

The poor samples from areas 4 and 5 in 1956 were due entirely to the scarcity of jurtina in spite of good collecting conditions.

TABLE 16

Comparison of spot-distribution in female $\mathrm{M}$. jurtina from four areas of Tean in 1954 and 1956

\begin{tabular}{|c|c|c|c|c|c|c|c|c|}
\hline Spots & o & I & 2 & 3 & 4 & 5 & Total & Difference \\
\hline \multirow{2}{*}{$\begin{array}{r}\text { Area I, I } 954 \\
\text { I } 95^{6}\end{array}$} & 30 & I 4 & 49 & I I & I & I & Iо6 & \multirow{2}{*}{$\begin{array}{l}\chi_{(3)}^{2}=0.201 \\
0.98>P>0.95\end{array}$} \\
\hline & 43 & 22 & 67 & I 5 & 5 & $\cdots$ & I 52 & \\
\hline \multirow{2}{*}{$\begin{array}{r}\text { Area } 2 * 1954 \\
1956\end{array}$} & $3^{I}$ & 19 & 55 & 3 & $\ldots$ & $\ldots$ & I 08 & \multirow{2}{*}{$\begin{array}{l}\chi_{(3)}^{2}=6.537 \\
\quad P>0.1\end{array}$} \\
\hline & 29 & $3 \mathrm{I}$ & 64 & 8 & 4 & I & I 37 & \\
\hline \multirow{2}{*}{ 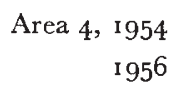 } & I3 & I7 & 62 & 8 & 6 & 3 & I09 & \multirow{2}{*}{$\begin{array}{l}\chi_{(3)}^{2}=2.013 \\
0.7>P>0.5\end{array}$} \\
\hline & 9 & 6 & 22 & 7 & I & $\cdots$ & 45 & \\
\hline \multirow{2}{*}{$\begin{array}{r}\text { Area } 5,1954 \\
1956\end{array}$} & I 3 & I 8 & 68 & II & 5 & $\cdots$ & I I 5 & \multirow{2}{*}{$\begin{array}{c}\chi_{(3)}^{2}=5.335 \\
0.2>P>0.1\end{array}$} \\
\hline & 9 & 7 & I5 & 5 & I & $\cdots$ & 37 & \\
\hline
\end{tabular}

* North edge.

From the values of $\chi^{2}$ it is clear that none of the populations has altered significantly during the two years in question. The extremely close accord in area $\mathrm{I}$ is of much interest since it is precisely what might be expected in this habitat: the only one of the four which has never been subject to change. Thus a comparison of the female samples for the four areas on Tean in 1956 (table I6) confirms our I 954 findings in respect of area 3 which still remained a barrier to $M$. jurtina, separating the populations to the south and west. It does so too in area I, 
which has never so far changed since the observations began in 1946 and for area 2 which represents an extension of area $I$ and again proved similar to it $\left(\chi_{(3)}^{2}=5.04 ; 0.2>\mathrm{P}>0.1\right)$. It will be noticed, however, that the populations in areas $4+5$ have begun to show a second, though slight, mode at o again, having been unimodal at 2 spots in 1954. That is to say, they are reverting to the form normal on Tean, probably because rabbit grazing was restoring the grass on the newly colonised area 4 to the conditions which had previously existed there when grazed by cattle. Consequently areas $I+2$ and $4+5$ are no longer significantly distinct in $195^{6}\left(\chi_{(3)}^{2}=2 \cdot 07\right.$; $0.7>\mathrm{P}>0.5$ ), as they were in 1954 .

\section{(ii) Great Ganilly}

Males were collected on Great Ganilly in I95 I, I955, I956 and I957, but not in 1953 (see tables 17 and 18 ). The combined samples over these four years are together highly heterogeneous $\left(\chi_{(6)}^{2}=30 \cdot 607\right.$, with $\mathrm{P}<\mathrm{O} \cdot \mathrm{OOI})$. Inspection suggests that this is due to a change which occurred between I 955 and I956. In the two years prior to $195^{6}$ the samples were, as expected, unimodal at two spots. In 1956 and I957 we encountered the entirely exceptional condition of male samples with a mode at more than two. The I95I and I955 distributions prove, in fact, to be homogeneous $\left(\chi_{(2)}^{2}=2 \cdot 80, \mathrm{P}>0 \cdot 2\right)$. Owing to the exceptionally hot, dry summer which brought out the species unusually early, the male sample in 1957 is too small to provide a detailed comparison with that of the previous year, though fig. I suggests that there has been a steady increase in male spotting between I955 and 1957: a trend which was found also in most other islands. The higher spot value of the small 1957 sample is not formally significant (for the comparison, $\chi_{(2)}^{2}=3 \cdot 81$, with $\mathrm{P}$ just under $0 \cdot 2$ ), but it is evident that its true mode must be either at 3 or 4 spots, not at 2 as in I95 I and I955.

An inspection of the 5 female samples from I95 to 1957 (table I8) suggests a distinct change in the spotting of that sex between $195 \mathrm{I}$ and 1953. All are bimodal at o and 2 spots, but in I95 I the greater mode is at $\mathrm{o}$, while subsequently and consistently it is at 2 . Indeed the 4 samples from 1953 to 1957 inclusive are homogeneous $\left(\chi_{(9)}^{2}=8 \cdot 27\right.$, with $\mathrm{P}=0.5$ approximately). The disparity of the $195^{\mathrm{I}}$ captures is not quite sufficient to produce total heterogeneity when compared with the other four years in a table of general contingency $\left(\chi_{(12)}^{2}=17 \cdot 48\right.$, with $\mathrm{P}$ between $\mathrm{O} \cdot \mathrm{I}$ and $\mathrm{0} \cdot 2$ ). When, however, the 4 samples from 1953 to I 957 are combined, which their homogeneity fully allows, and then compared with the one from $195^{\mathrm{I}}$ in a $2 \times n$ table, the distinction of the latter is established, for then $\chi_{(3)}^{2}=9 \cdot 05$, with $\mathrm{P}$ between 0.05 and 0.02 .

It appears, therefore, that some change has affected the Maniola jurtina population of Great Ganilly; one which influenced the females before the males and tended still further to increase the spot-averages 
of both sexes. This was perhaps of an ecological kind, but its nature is not clear. When, on studying our results up to I955 (Dowdeswell et al., 1957), we first had some indication of such an adjustment, our comment was: "The vegetation of Great Ganilly differs somewhat from that of any small island we have studied so far, consisting of a

TABLE I7

Great Ganilly-males

\begin{tabular}{|c|c|c|c|c|c|}
\hline Spots & I95 I & 1955 & I 956 & I957 & Total \\
\hline $\begin{array}{l}\mathrm{O} \\
\mathrm{I} \\
2 \\
3 \\
4 \\
5\end{array}$ & $\begin{array}{r}\ldots \\
2 \\
33 \\
27 \\
\text { I } 3 \\
\text { I }\end{array}$ & $\begin{array}{r}\ldots \\
I \\
20 \\
10 \\
I \\
2\end{array}$ & $\begin{array}{r}\mathrm{I} \\
\mathrm{I} \\
3 \mathrm{I} \\
48 \\
38 \\
5\end{array}$ & $\begin{array}{r}\ldots \\
\ldots \\
3 \\
8 \\
9 \\
4\end{array}$ & $\begin{array}{r}\mathrm{I} \\
4 \\
87 \\
93 \\
6 \mathrm{I} \\
\mathrm{I} 2\end{array}$ \\
\hline Total & 76 & 34 & I 24 & 24 & $25^{8}$ \\
\hline
\end{tabular}

No male sample was taken in 1953 .

luxuriant growth of various grasses. There is, in addition, much heather interspersed with short grass, which is to be found mainly on the higher ground. It may be that in these abnormal circumstances the insect is particularly sensitive to small environmental changes."

TABLE 18

Great Ganilly_females

\begin{tabular}{|c|c|c|c|c|c|c|}
\hline Spots & I95 I & 1953 & I955 & I 956 & I957 & Total \\
\hline $\begin{array}{l}\text { O } \\
\text { I } \\
2 \\
3 \\
4 \\
5\end{array}$ & $\begin{array}{r}41 \\
7 \\
37 \\
8 \\
5 \\
\ldots\end{array}$ & $\begin{array}{r}32 \\
13 \\
52 \\
6 \\
2 \\
\ldots\end{array}$ & $\begin{array}{r}\text { I } 3 \\
9 \\
33 \\
6 \\
\text { I } \\
\ldots\end{array}$ & $\begin{array}{c}27 \\
17 \\
35 \\
10 \\
2 \\
2^{*}\end{array}$ & $\begin{array}{r}20 \\
10 \\
27 \\
7 \\
3 \\
\ldots\end{array}$ & $\begin{array}{r}\text { I33 } \\
56 \\
\text { I84 } \\
37 \\
\text { I3 } \\
2\end{array}$ \\
\hline Total & 98 & 105 & 62 & 93 & 67 & $4^{25}$ \\
\hline
\end{tabular}

* One of these is actually at 6 .

The accumulating information of two further seasons certainly suggests that some change in the habitat, to which the females responded first, has produced a new and perhaps stabilised spot-distribution in the $M$. jurtina population inhabiting it.

\section{(iii) The Island of Arthur}

We had collected on Arthur, an island of about 25 acres, both in I95 I and 1953. On neither occasion was the population large; though two of us (Dowdeswell and Ford, 1955) were at work for five 
or six hours, our totals amounted only to 64 and 77 females respectively. We did not catch males there in either year. The female spotfrequencies proved to be of a highly unusual type, with a very large mode at 2 and a second slight one at $o$. The latter was only suggested in I953, the numbers at o and I spot being equal. It is an impressive fact that such a distinctive spot-distribution as that encountered in I95I should be reproduced so closely two years later (for the comparison, $\chi_{(3)}^{2}=I \cdot 99$, for which $\left.\mathrm{P}>0.5\right)$.

A visit to the island is not easily combined with other work, and we could not collect there again until 1957 . We then found the population reduced to an extremely low level. Two of us (K. G. McW. and E. B. F.) working for about six hours in good conditions, obtained only 9 females and 3 males. Two of these were caught upon Middle Arthur;

TABLE 19

Spot-distributions of a sample from the Island of Arthur, 1957

\begin{tabular}{|c|c|c|}
\hline Spots & Male & Female \\
\hline \multirow[t]{2}{*}{ 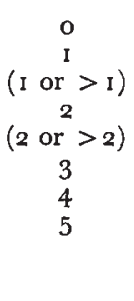 } & $\begin{array}{l}\ldots \\
\ldots \\
\ldots \\
\ldots \\
\ldots \\
\mathrm{I} \\
\mathrm{I} \\
\mathrm{I} \\
\mathrm{I}\end{array}$ & $\begin{array}{c}\mathrm{I} \\
\ldots \\
\dddot{(\mathrm{I})} \\
5 \\
(\mathrm{I}) \\
\mathrm{I} \\
\ldots \\
\ldots\end{array}$ \\
\hline & 3 & 9 \\
\hline
\end{tabular}

* These specimens are from Middle Arthur.

this is a small island connected with the main one by a shingle bar about 5 5 yards long, over which the waves break in rough weather, though it is never actually submerged. The results are shown in table 19. It will be seen that they do not make it possible to estimate the spot-distribution in either sex, except that the large female mode at 2 spots, characteristic of the previous years, is at least suggested this season.

Since the population on Arthur had evidently reached an extremely low density in 1957 , it will be important to determine whether the female spot-frequencies there retain their characteristic and unusual form if the numbers should rise again. Should they do so, we shall have a further opportunity to test the theory of "intermittent drift" put forward by Waddington (I957, p. 86) as an explanation of the spotdistributions of this butterfly in Scilly, one which we already have the strongest evidence to disprove (pp. 36I-2).

\section{(iv) White Island}

This small island lies off the north-west coast of St Martin's and is connected with it at low tide. The population of M. jurtina on White 
Island is undoubtedly isolated by at least 225 yards of rocky terrain from that occupying the shore of St Martin's (see fig. 3). Dowdeswell et al. (1957) have described the local situation and a preliminary account of an experiment involving the planting of White Island females on the St Martin's coast is given on pp. 348-50.

We did not collect a sample on White Island in 1956 . In 1957 we made two visits and found the collecting area somewhat affected by drought; the population appeared to be smaller than usual, though

TABLE 20

Comparison of female M. jurtina on White Island in 1957 with samples of 1953-55

\begin{tabular}{|c|c|c|c|c|c|c|c|c|c|}
\hline Spots & 0 & $\mathrm{I}$ & 2 & 3 & 4 & 5 & Total & $\begin{array}{c}\text { Spot } \\
\text { average }\end{array}$ \\
\hline $\mathrm{I} 953-5$ & $\mathrm{I} 72$ & 90 & 64 & $\mathrm{I}$ & $\ldots$ & $\ldots$ & 327 & 0.68 & $\chi_{(2)}^{2}=0.074 ;$ \\
$\mathrm{I} 957$ & 37 & 18 & $\mathrm{I} 2$ & $\ldots$ & $\ldots$ & $\mathrm{I}$ & 68 & 0.69 & $0.98>\mathrm{P}>0.95$ \\
\hline
\end{tabular}

there was no approach to the decimation which we found on $\mathrm{St}$ Mary's and Tresco. Table 20 presents the results of the catch and it will be readily seen that the females have remained stable with a high mode at o spots, as in 1953-55.

In previous years we had not attempted to catch male specimens here in order to save time for other commitments. The maintenance of the high stability of the population into I957, however, gave us the

TABLE $2 \mathrm{I}$

Spot-distribution and spot-average of male M. jurtina on White Island, 1957

\begin{tabular}{|c|c|c|c|c|c|c|c|c|}
\hline Spots & 0 & $\mathrm{I}$ & 2 & 3 & 4 & 5 & Total & $\begin{array}{c}\text { Spot- } \\
\text { average }\end{array}$ \\
\hline $\mathrm{I} 957$ & $\mathrm{I}$ & 4 & $\mathrm{I} 1$ & 2 & $\mathrm{I}$ & $\mathrm{I}$ & 20 & $2 \cdot 05$ \\
\hline
\end{tabular}

opportunity of checking whether the correlation of male and female spot-averages, which was a feature of the stable mainland populations in $1950-52$ and of at least some of the more highly spotted populations. of the Isles of Scilly between 1946 and r955, could also be found in White Island. Only 20 males were caught in 1957 and their spotdistribution and spot-average are recorded in table $2 \mathrm{I}$.

If the two I 957 spot-averages (females 0.69 ; male 2.05) are entered on a graph ( $c f$. McWhirter, 1957) the datum falls among a group of South England populations of the 1950-52 period. Our male sample (although it was rather a small one) appears to be correlated in the same way as in the mainland populations with the female sample. 
We now have three bi-sexual samples from low spot-average populations in Scilly, including that from Bryher, I95 I, and that from the population on the coast of St Martin's opposite White Island (Top Rock Valley) in 1957 , and all three sets of data support this suggestion (fig. I).

\section{DISCUSSION}

The de-stabilisation of the large island populations which began in 1956 has fortunately given us an opportunity of studying the process on terrain of which we have an intimate knowledge. It has already enabled us to test certain theories of population dynamics and we may expect that, as the cycle completes itself, further deductions may be drawn concerning the nature and strength of stabilising selection in the field.

It seems clear that the process of de-stabilisation began after the effect of a series of droughts had accumulated to such an extent that the supply and quality of the food-plants of $M$. jurtina were being adversely affected and liability to predation perhaps increased (see p. 339 and pp. 348-50). This had the expected result (McWhirter, I957) of reducing the relative viability of high-spotted females. Yet the reaction of $M$. jurtina on the three large islands was interestingly different in each case; nil on St Mary's; stepwise and moderate, on St Martin's; violent, on Tresco. This grading of the reaction corresponds with three types of ecological difference. Firstly, the size of the Main Areas of the three islands, that is those areas known to be occupied by populations exhibiting the "flat-top" distribution, varies: St Mary's Main Area is the largest; St Martin's Main Area comes next; Tresco Main Area is the smallest. Secondly, although no quantitative study has yet been attempted, it is probable that the actual sizes of the $M$. jurtina populations are in the same order. St Mary's offers far more acreage suitable to $M$. jurtina than does St Martin's, but the density of the insect on St Mary's is probably rather lower. On Tresco both available acreage and density are much lower than on the other two islands. Thirdly, it happens that the amount of cultivation on St Mary's is greater than that on St Martin's (taken as a whole), while the main area of Tresco is wholly uncultivated. Since conservation of moisture in a sandy soil is one of the main effects of the intensive and efficient agriculture (or horticulture) of Scilly, it is reasonable to suppose that the recent ecological shock was buffered more on St Mary's than elsewhere, and least of all on Tresco. We are strongly inclined to put forward this third comparison as the explanation of the differing reactions; we are dealing with very strong selection pressures which will act as readily on a very large population as on one of moderate size. The slight, presumably genetic, difference between the St Mary's population and the other two, whereby more insects with 3 or more spots are consistently found on St Mary's, may also suggest a greater innate ability to resist the unfavourable effects of drought (p. 336). 
An important feature of the present phase of stabilisation in the large islands is that, although there has been a sharp move towards lower spotting in the females, the trend in the males has been in the other direction, towards higher spotting. It is possible that the population on St Mary's is also taking part in this move, even though its females still remain stabilised. Table 22 and fig. I illustrate the similarity of response on the three large islands, though it must be emphasised that the I 957 value for St Mary's could only be based on Io specimens and might be misleading.

A tendency towards higher male spotting seems to have begun in 1956 and continued in 1957. It is quite possible that the ecological

TABLE 22

Comparison of spot-averages of male and female samples of $\mathrm{M}$. jurtina from the three large islands of Scilly

\begin{tabular}{|c|c|c|c|c|c|c|}
\hline \multirow{2}{*}{ Island } & \multicolumn{2}{|c|}{$\begin{array}{l}\text { Range of spot-averages } \\
\text { during period of stabilis- } \\
\text { ation, I } 950-55\end{array}$} & \multicolumn{2}{|c|}{$\begin{array}{l}\text { Spot-averages } \\
\text { in } 195^{6}\end{array}$} & \multicolumn{2}{|c|}{$\begin{array}{l}\text { Spot-averages } \\
\text { in } 1957\end{array}$} \\
\hline & Males & Females & Males & Females & Males & Females \\
\hline St Martin's & $2 \cdot 14^{-2} \cdot 23$ & o.99-I'I9 & $2 \cdot 23$ & 0.95 & $2 \cdot 3^{8}$ & 0.93 \\
\hline Tresco & $2 \cdot 12-2 \cdot 21$ & $I \cdot I 4-I \cdot 24$ & $2 \cdot 29$ & $I \cdot I 5$ & $2 \cdot 60$ & $0.8 \mathrm{I}$ \\
\hline St Mary's & $2 \cdot 32$ & I. I $2-I \cdot 43^{*}$ & $\ldots$ & $\ldots$ & $2 \cdot 80$ & $I \cdot 29$ \\
\hline
\end{tabular}

* It should be noted that the range of female spot-averages on St Mary's is not so great as these figures suggest. The low reading (I.I2) is from the I95 I sample; since I 954, when the island was next visited, there has been a steady tendency for the St Mary's females to show a high " tail" of insects with 3,4 or 5 spots and this has maintained the spot-average between I $\cdot 29$ and I 43 .

stresses described on pp. 34 I-2 have opposite effects on the males and on the females or that this increase in male spotting is part of a trend oberved all over Southern England and Cornwall. It is clear, at any rate, that the three populations were stable between I950 and I 955 and that the male and female spot-averages conformed to the general correlation, oberved not only in Scilly but all over Britain (McWhirter, I957, fig. I). When de-stabilisation began in 1956 this correlation between the sexes was broken. Clearly this is a phenomenon comparable with the break-down in correlation observed at the sensitive " boundary" area between Devon and Cornwall (Creed et al., I959). Until the results of individual breeding tests are available, evidence that spotting is to a large extent heritable must be deduced from population data. Male and female spot-averages are usually strongly correlated in stabilised populations. They tend to deviate from this correlation only in genetically "sensitive" contexts, where 
selection-pressures appear to be marginal or in the process of changing. We have here one reason for excluding any extreme environmentalist argument that spotting is a phenotypic phenomenon.

That the "flat-top" stabilisation is governed by a special genetic condition and is not a mere admixture of differently adjusted subpopulations, is proved by the local homogeneity of the St Martin's Main Area samples. We happened to test this for the first time in a year when the population had switched to its characteristic alternative stabilisation; but this was found in three well separated collecting areas (fig. 3).

It seems to be in the nature of stabilised populations that they are insulated against numerous ecological variations (especially, perhaps, those which are frequently experienced); the factors which in Scilly and possibly on the mainland seem to upset stabilisation are in some way linked with the abundance or luxuriance of grass. Stabilisation, however, cannot be regarded as a condition akin to passivity, in which " nothing much" happens to the population, so that it quietly maintains its "ordinary" structure. Such an idea would be utterly contrary to the fundamentals of the theory of natural selection. Stabilisation is the reflection of a dynamic, multi-dimensional, equilibrium. It is scarcely necessary to emphasise that the selective forces maintaining the equilibrium are powerful ones. In $M$. jurtina some hundreds of candidates for parenthood are in an average year reduced to a mere two. While much of this elimination will be random with respect to the particular characters studied, there is ample room for strong selective effects. Indeed rearing experiments by W. H. Dowdeswell show that the genes which control spotting in $M$. jurtina influence the body in other and important ways. When, therefore, in an area of stabilisation, certain of the conflicting forces are strengthened or reduced, and the buffering system supporting the relevant selective factors in the micro-ecological norm collapses, the response of the stabilised organism is likely to be rapid and decisive: in fact, quantised.

Thus we would expect, once we had obtained sufficient background information to establish what is the "normal" equilibrium relating organism and environment, that changes, when they occur, would often be large and sudden rather than small and gradual. Since in practice a micro-ecological buffering system will probably tend to be modifiable in a limited number of directions, the quantum-changes of selective values and of the resultant pressures on the organism will also tend to follow certain definite paths and arrive at new and specific optimal conditions. This would provide the easiest explanation of the "clumping" which can be observed in the spot-distributions of female populations of $M$. jurtina, despite their isolation in various habitats in the Isles of Scilly. Now that the old large-island stabilisation has been, for the time being at least, broken up, we have the opportunity of observing the dynamics of stabilisation both from the 
genetical and from the micro-ecological points of view in three populations between which no gene-flow can take place. In $M$. jurtina, the quantum-changes which we have observed locally, inter-seasonally and intra-seasonally, and the system of alternative equilibria, which is now beginning to present a clearer picture, argue powerfully for the concept of stabilisation being maintained by strong selective forces.

Waddington (1957) has put forward an explanation of the variation between the populations of $M$. jurtina in the small islands of Scilly, which he terms " intermittent drift". Chance survival of certain genotypes when the population is strongly reduced could, according to his view, result in the development of variant populations in isolated habitats as soon as conditions allowed of re-expansion. By observing populations of $M$. jurtina it is possible to test this hypothesis in two ways:

(i) large populations should be found to be stable;

(ii) small populations should sometimes be found to have changed on re-expansion.

One might fairly often find a reduced population reconstructing itself as it was before merely by chance unless indeed the spot-distribution concerned was a very uncommon one. Consequently a series of results might be needed before the second test could be applied.

On the other hand, we have ample data which allow us to apply the first test and in every case we are led to reject Waddington's hypothesis. Generally we find that large populations are remarkably stable, but we have now studied five instances in which they have been transformed. The extent of the transformation is usually of the same order as the difference between populations which are adjusted to isolated habitats. The five areas are listed in table 23.

It will be seen from the above that there is no need to invoke any hypothesis of "intermittent drift" to explain the existing observed differences of spot-distributions. Large populations, though usually stable, can from time to time undergo radical and sudden transformations and these can occur without reduction to small numbers. Fluctuations in numbers do, of course, offer exceptional opportunities for evolutionary change (see, for instance, Ford and Ford, 1930, on Melitea aurinia) but even when they occur the bias given to the reexpanding population will be determined by the selective factors in force during the decline and during the early phase of the re-expansion when genetic reorganisation may be taking place. In most of the instances listed above, however, selection has been strong enough to operate on very large populations. The selective disadvantage of 60 per cent. suffered by the high-spotted Tresco females in 1957 is the largest selection-pressure so far calculated in a wild animal in its natural habitat. We have explained elsewhere (Creed et al., 1959) why we do not hesitate to think in these terms. The few instances so far in which the strength of natural selection has been adequately 


\begin{tabular}{|c|c|c|c|c|c|}
\hline 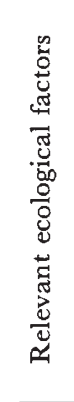 & 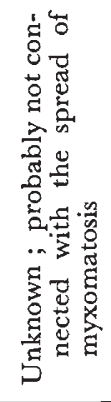 & 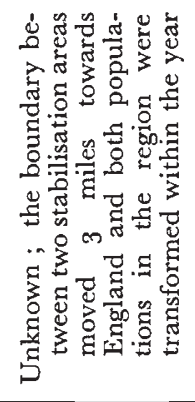 & 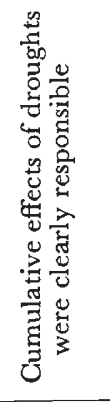 & 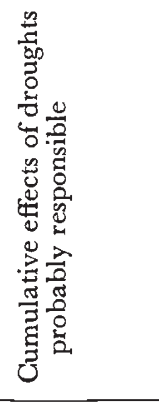 & 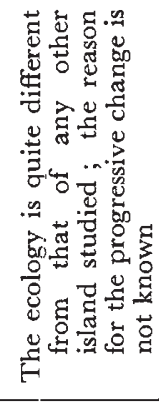 \\
\hline 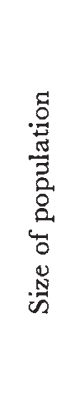 & 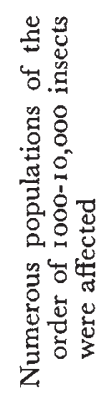 & 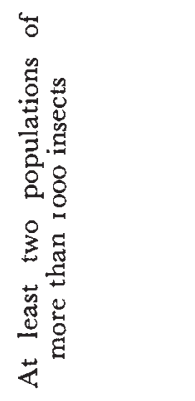 & 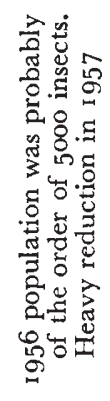 & 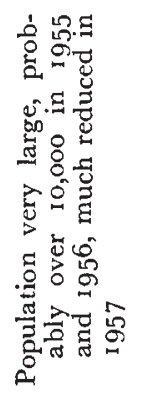 & 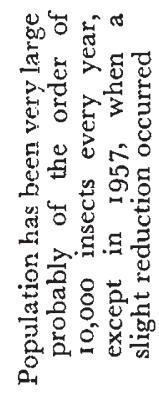 \\
\hline 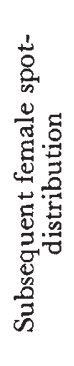 & 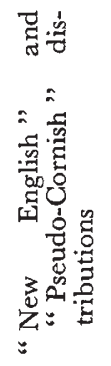 & 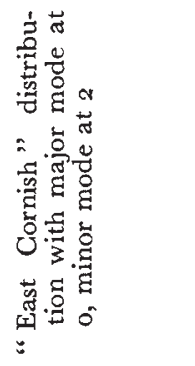 & 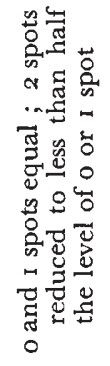 & 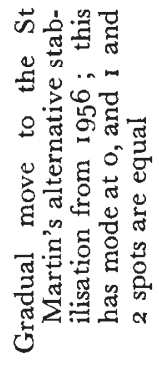 & 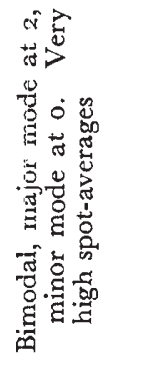 \\
\hline 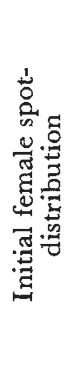 & 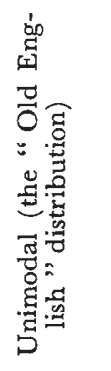 & 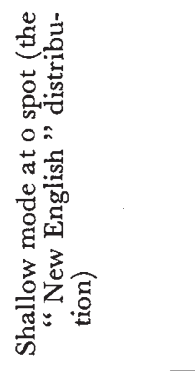 & 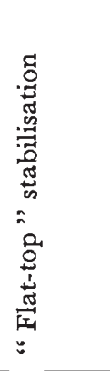 & 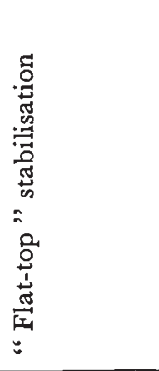 & 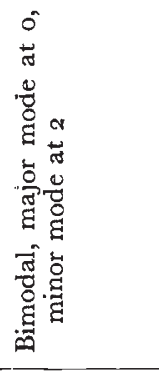 \\
\hline 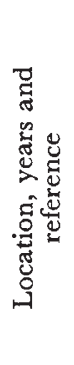 & 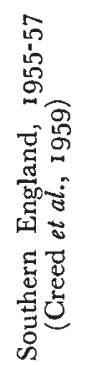 & 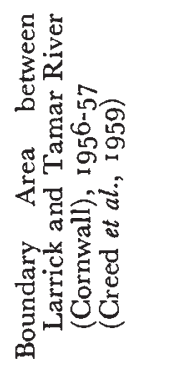 & 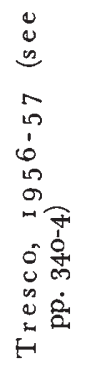 & 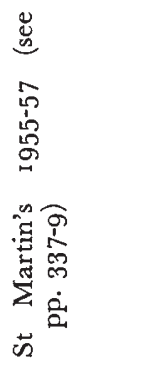 & 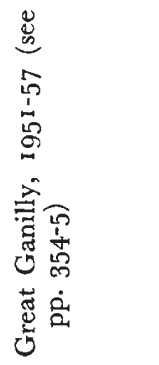 \\
\hline
\end{tabular}


tested have combined to demonstrate that it is a far more powerful agent than was generally supposed.

\section{SUMMARY}

I. Our work upon the evolution of the butterfly Maniola jurtina in the Isles of Scilly is here summarised for the years I 956-57.

2. As in the past, we have used a quantitative character, the number of spots on the underside of the hind wings, for analysing the variability of this insect.

3. The "flat-topped" distribution, with approximate equality at $\mathrm{O}$, I and 2 spots, characteristic of the females in the large islands, had previously persisted throughout our work.

4. In $195^{6}$ on St Martin's, and in 1957 on Tresco, the stability of the populations broke down to produce a reduction in female, but an increase in male, spotting. However, on St Mary's, the largest and most varied island of the three, the original spotting-type persisted unaltered.

5. The new spot-distributions were correlated with drought which produced an acute shortage of grass, except upon St Mary's.

6. This rapid change in two large populations of Maniola jurtina on Scilly in response to exceptional ecological conditions is fatal to Waddington's theory of " intermittent drift", by which he attempts to explain the uniformity of this insect on the large islands and its difference from one to another of the small islands.

7. By dividing St Martin's into sub-areas, it was shown that the population there is homogeneous, not a mixture of differently adjusted sub-populations.

8. If the uniformity of spotting on the large islands is obtained in response to the average of the conditions there, any small isolated areas upon them may achieve local and differing adjustments. Three such areas have been studied in 1956-57 (one on Tresco and two on St Martin's) and the existence of such local adjustments in them has been proved and analysed.

9. The spot-frequencies of Maniola jurtina were studied upon four of the small islands.

ro. These frequencies have not changed on White Island; nor have they done so on Tean since the removal of cattle late in $195^{\circ}$ produced a profound difference in the ecology, and consequently in the spotting of Maniola jurtina, in certain areas.

II. The butterfly has become very rare on the island of Arthur, while on Great Ganilly an increase in male spotting between 1955 and I 956 has produced the exceptional condition of a mode at 3 spots. An increase in female spotting, to convert the minor mode at 2 spots into a major one, had occurred earlier, between I95 I and 1953 .

12. Our results show that the characteristic spot-distributions of the various Maniola jurtina populations in Scilly are both maintained 
and adjusted by extremely powerful selection-pressures which, in the exceptional conditions of 1957 on Tresco, could be assessed as a 60 per cent. elimination of high-spotted females.

Acknowledgments.-We should like to express our grateful thanks to the Nuffield Foundation for their financial support of this work and to Lt.-Cdr. T. DorrienSmith, R.N. for his kind permission to camp on Tean. We are indebted to Dr N. T. J. Bailey for statistical advice, especially in regard to the use of Woolf's " $x$ ", statistic, to Miss Christine Court of the Department of Human Anatomy, Oxford, for kindly drawing figs. I-3, to $\mathrm{Mr}$ E. R. Creed for his help in preparing the typescript and figures and to Mr J. E. Lousley, of the Botanical Society of the British Isles, for an opinion on the botany of the Isles of Scilly.

\section{REFERENCES}

CREED, E. R., DOWDESWELL, W. H., FORD, E. B., AND MCWHIRTER, K. G. I959. Heredity, I3, 363-392.

DOWDESWell, w. H., Fisher, R. A., AND Ford, E. B. 1949. Heredity, 3, 67-84.

DOWDesWell, W. H., AND FORD, E. B. 1953. Symposia Soc. Exp. Biol., 7, 254-273.

DOWDESWEll, W. H., AND FORD, E. B. 1955. Heredity, 9, 265-272.

DOWDESWEll, W. H., FORD, E. B., AND MCWHIRTER, K. G. 1957. Heredity, II, 5 I-65.

FISHER, R. A., AND FORD, E. B. 1947. Heredity, 1, I 43-I 74 .

FORD, H. D., AND FORD, E. B. 1930. Trans. Ent. Soc. Lond., 78, 345-351.

MCWHIRTER, K. G. I957. Heredity, II, 359-37I.

waddington, C. H. 1957. The Strategy of the Genes. Allen and Unwin, London. woolf, B. 1954. Ann. Hum. Genet., 19, 25 I-253. 